\title{
Substrate selection by blue crab Callinectes sapidus megalopae and first juvenile instars
}

\author{
Jacques van Montfrans ${ }^{1, *}$, Clifford H. Ryer ${ }^{2}$, Robert J. Orth ${ }^{1}$ \\ ${ }^{1}$ Virginia Institute of Marine Science, The College of William and Mary, Gloucester Point, Virginia 23062, USA \\ ${ }^{2}$ Fisheries Behavioral Ecology Program, Alaska Fisheries Science Center, NMFS/NOAA, \\ Hatfield Marine Science Center, Newport, Oregon 97365, USA
}

\begin{abstract}
Various marine and estuarine species utilize chemical cues during settlement. We investigated responses by megalopae and first juvenile (J1) blue crabs to common Chesapeake Bay substrates in mesocosm and field experiments. Mesocosm trials examined responses of megalopae or J1 crabs to sand, marsh mud, live oysters Crassostrea virginica, sun-bleached oyster shell, eel grass Zostera marina and artificial seagrass in replicate $160 \mathrm{l}$ tanks. Either 10 megalopae or J1 crabs isolated in each of 6 substrates were allowed total access after acclimation to test the null hypothesis of equal distribution among substrates after $13 \mathrm{~h}$. Thirty-five percent of megalopae were recovered from $Z$. marina, with the remaining substrates containing fewer than half that many. In contrast, $30 \%$ of $\mathrm{J} 1$ crabs (with only $17 \%$ recovered from $Z$. marina) were found in live $C$. virginica. A field experiment quantified responses of ingressing megalopae to $Z$. marina, marsh mud, and $C$. virginica. Overnight settlement was significantly higher in $Z$. marina ( $\bar{x}=3.3$ ind.; $60 \%$ of total) when compared to mud $(\bar{x}=0.9 ; 16 \%)$ or C. virginica $(\bar{x}=1.3 ; 24 \%)$. Likewise, J1 crabs were significantly more numerous in $Z$. marina $(\bar{x}=3.7$ ind.; $55 \%$ of total) than in C. virginica $(\bar{x}=1.8 ; 27 \%)$ and mud $(\bar{x}=1.2 ; 18 \%)$. $\mathrm{J} 1 \mathrm{crab}$ distribution in field plots likely reflected habitat selection by megalopae; laboratory results were equivocal and probably due to artifacts associated with density-dependent agonism. The initial non-random distribution of blue crabs in Chesapeake Bay may be deterministic and due to habitatselection behavior by megalopae. Selection for seagrass assures the greatest likelihood of maximal survival and accelerated growth. Similar relationships may also exist in estuarine-dependent species with comparable habitat requirements and life-history characteristics.
\end{abstract}

KEY WORDS: Blue crab · Megalopae - First juvenile instar - Habitat selection · Zostera marina • Crassostrea virginica $\cdot$ Sand $\cdot$ Mud

\section{INTRODUCTION}

Many marine and estuarine organisms are patchily distributed by physical processes controlling the supply of recruits to suitable habitats. Others exhibit active lar$\mathrm{val} /$ postlarval behavior during recruitment that assures a habitat-specific association upon settlement (Hadfield 1984, Scheltema 1974, 1986, Butman 1987, Butman et al. 1988, Morse 1990, Pechenick 1990, Young 1990, Rodriquez 1993) This behaviour may be particularly important in species that have both strong swimming capabilities and highly developed sensory systems (Connell 1985, Scheltema 1986, Butman 1987).
Among species of Brachyura and Palinura, for example, many exhibit life cycles with widely dispersing larvae (zoeae, glaucothoe) and postlarvae (megalopa, puerulus). These stages display swimming capabilities that increase ontogenetically, and often, the early juvenile stages are distributed non-randomly in nature (Botero \& Atema 1982, Orth \& van Montfrans 1987, Jensen 1989, Boudreau et al. 1990, O'Connor 1991, Fernandez et al. 1993). Such evidence suggests that the recruiting phase in the life cycle settles preferentially in specific (i.e. nursery) habitats.

Settling stages of decapods respond to various chemical and physical habitat characteristics that likely in- 
volve the integration of multiple sensory modalities. Some decapods settle in response to (1) adult conspecifics (e.g. Petrolisthes cinctipes and P. eriomerus, Jensen 1989; Uca pugilator, O'Connor 1991), (2) light characteristics of crevices (e.g. Homarus americanus, Botero \& Atema 1982, Boudreau et al. 1990), (3) habitat structural characteristics (e.g. Homarus americanus, Botero \& Atema 1982, Boudreau et al. 1990; Cancer magister, Fernandez et al. 1993; Panulirus argus, Hernkind \& Butler 1986; Carcinus maenas, Hedvall et al. 1998), (4) habitat-related chemical cues (Callinectes sapidus, Welch et al. 1997), (5) presence of an appropriate host in symbiotic species (e.g. Echinoecus pentagonus, Castro 1978) and (6) avoidance of potential predators (C. sapidus, Welch et al. 1997, Diaz et al. 1999). Larvae and postlarvae of several species delay metamorphosis in the absence of suitable cues (Pechenik 1990, O'Connor 1991, Harvey 1993). These studies imply that highly selective larval or postlarval behavior during recruitment, combined with strong mobility, likely plays a key role in selection of preferred nurseries during recruitment.

Habitat-specific associations for the blue crab Callinectes sapidus occur in many areas throughout its range. Within Chesapeake Bay, megalopae and smallest juvenile crabs occur principally in seagrass meadows (e.g. Zostera marina and Ruppia maritima; Orth \& van Montfrans 1987, 1990) whereas elsewhere, they may be associated with marsh habitats (Thomas et al. 1990, Rozas \& Minello 1998, Minello 1999). Whereas adults and juveniles are estuarine dependent (Williams 1984), larvae require high-salinity oceanic waters and are advected from the estuary in surface waters (Costlow \& Bookhout 1959). The megalopa (postlarva) stage is the recruiting phase in the life cycle, with ingress into the Chesapeake Bay and its tributaries accomplished between July and the end of November each year (van Montfrans et al. 1990, 1995) via a combination of seasonal physical processes (Epifanio 1988a,b, Epifanio et al. 1984, 1989, Goodrich et al. 1989) and vertical migratory behavior of megalopae (Mense \& Wenner 1989, De Vries et al. 1994, Olmi 1994, 1995, Tankersley \& Forward 1994, Forward et al. 1995). Given the fact that estuarine cues accelerate megalopal metamorphosis (Forward et al. 1994, 1996, Wolcott \& DeVries 1994), it is likely that sensory capabilities also exist for detecting the presence of specific estuarine habitats. When coupled with strong swimming capabilities of up to $12.6 \mathrm{~cm} \mathrm{~s}^{-1}$ (Luckenbach $\&$ Orth 1992), such sensory capacity may also enable the active selection of these habitats within the estuary. In this study, we investigate the ability of megalopae and first juvenile crabs to discriminate between commonly available habitats in Chesapeake Bay and examine the relative role of physical vs chemical cues in habitat selection via laboratory and manipulative field experiments.

\section{MATERIALS AND METHODS}

Laboratory experiments. Experiments were conducted in a wet lab facility at the Virginia Institute of Marine Science, Gloucester Point, Virginia. We tested the response of megalopae or laboratory-metamorphosed first juvenile stage crabs (hereafter referred to as J1 crabs) to 6 habitat types. Five of the habitat types selected (natural sand, natural marsh mud, live oysters Crassostrea virginica, sun-bleached oyster shell, and live eelgrass Zostera marina) are common to Chesapeake Bay and 1 (artificial Z. marina constructed from polypropylene ribbon) was an inert analogue of $Z$. marina plants.

Live Zostera marina and oyster substrates were thoroughly cleaned with a cloth and brush, respectively, and therefore likely contained only a light compliment of fouling organisms (e.g. diatoms) but differed from inert, unfouled substrates (artificial Z. marina and sun-bleached oyster shell) which were devoid of such influences. Additionally, the live and inert substrates (i.e. live vs artificial $Z$. marina and live vs sun-bleached oyster shell) were similar in overall dimension. Simulated ( $5 \mathrm{~mm}$ wide) and live $Z$. marina ( 3 to $4 \mathrm{~mm}$ wide) substrates spanned the height of the water column $(\sim 30 \mathrm{~cm})$ in experimental tanks and were established at low densities equivalent to 180 shoots $\mathrm{m}^{-2}$, characteristic of fall (Orth \& Moore 1986). Live oysters $(n=8)$ and oyster shells ( $\mathrm{n}=16$ half shells) were similar in length $(\bar{x}=74.7 \pm 5.6)$ and width $(\bar{x}=53.1 \pm 5.8)$, though sun-bleached oyster shells were not hinged.

Substrates were tested in replicate 1601 cylindrical fiberglass mesocosms ( $42 \mathrm{~cm}$ high $\times 70 \mathrm{~cm}$ wide) fitted with a central standpipe (Fig. 1). Mesocosm bottoms, filled to approximately $4 \mathrm{~cm}$ with sieved beach sand (grain size $<0.5 \mathrm{~mm}$; total surface area available = $0.38 \mathrm{~m}^{2}$ ), were divided into 6 equal, contiguous pieshaped sections (surface area $=0.06 \mathrm{~cm}^{2}$ each) into which substrates were randomly placed. The entire area of each pie-shaped tank section was covered by the experimental substrates being tested. Tanks were oriented randomly by compass heading within the laboratory prior to each trial to nullify tank orientation as a factor in laboratory experiments. A central standpipe (37.5 $\mathrm{mm}$ outside diameter) in each mesocosm was plugged with a rubber stopper at the bottom and fitted below the sediment surface with one screened (1 $\mathrm{mm}$ mesh; small enough to retain megalopae and J1 crabs but not the sand) drain plug per pie-shaped section. A series of similarly screened holes in the standpipe at the air-water interface facilitated water circulation and oxygenation via an air stone placed within the standpipe (Fig. 1).

Water circulation in each tank was minimal and considerably below the swimming capability of megalopae and J1 crabs (Luckenbach \& Orth 1992, J. van 

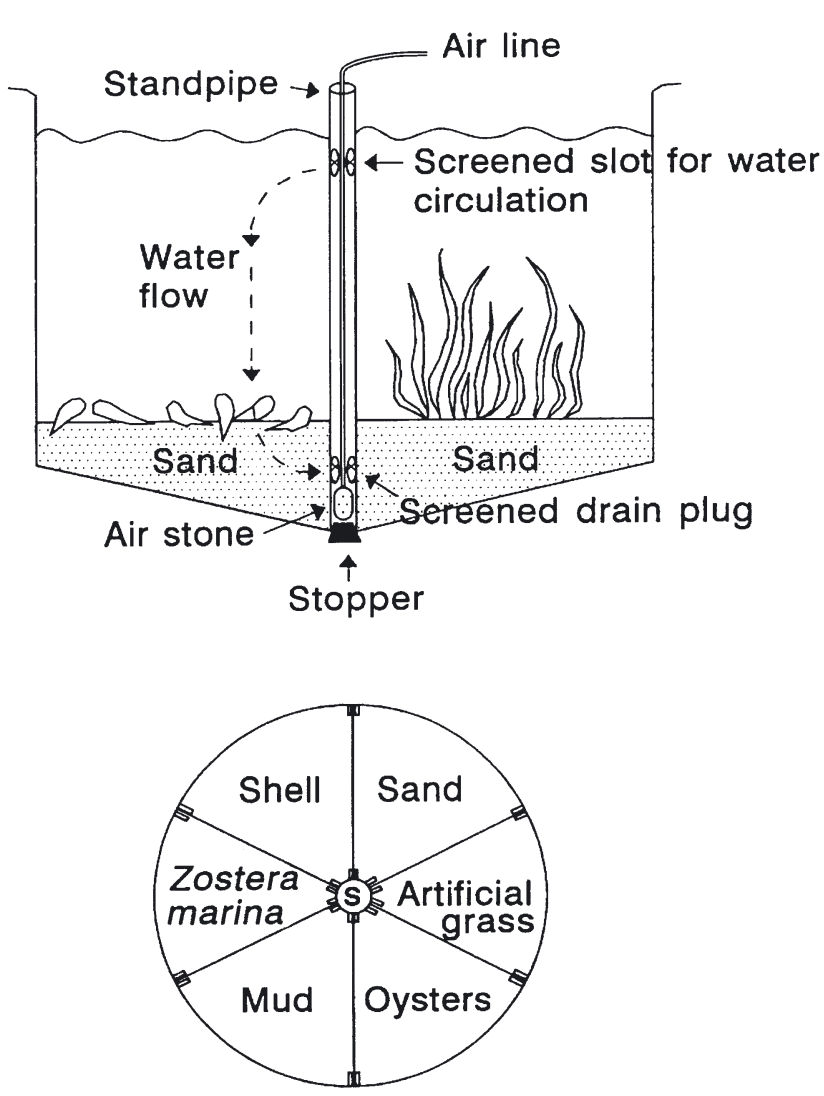

Fig. 1. Experimental mesocosm design. Top: tank cross section; bottom: top view. S: standpipe

Montfrans pers. obs.). Plastic sleeves attached to both the standpipe and opposing mesocosm sides enabled the removal (at the start of an experiment) and insertion (upon termination) of solid plastic partitions for either exposing or isolating adjacent mesocosm sections and associated experimental organisms, respectively. The 6 sections could thereby be isolated and the mesocosm emptied after partially removing the rubber stopper and allowing the water in each section to slowly drain via the screened drain plugs in the standpipe. Subsequently, upon complete removal of the stopper and the sequential removal of each screened drain plug, the contents of each randomly chosen section was individually rinsed through a $1 \mathrm{~mm}$ mesh sieve, thereby allowing experimental organisms, but not sediment, to be retained. Recovered individuals (88 to $100 \%$ efficiency) were then enumerated and examined for indications of molting (e.g. metamorphosis of megalopae).

Experimental trials utilizing either megalopae (18 September, $\mathrm{n}=4$ replicate tanks; 7 October, $\mathrm{n}=5$ ) or $\mathrm{J} 1$ crabs (28 September, $\mathrm{n}=7 ; 7$ November, $\mathrm{n}=6$ ) were conducted to test the null hypothesis of uniform distribution among the 6 experimental substrates. All labo- ratory experiments utilized either megalopae collected by a plankton net from the same site in the York River (Virginia Institute of Marine Science Ferry Pier; average salinity $\sim 18 \mathrm{ppt}$ ) or J1 crabs that underwent the metamorphic molt from plankton-collected megalopae in laboratory mesocosms devoid of natural substrates. Within $48 \mathrm{~h}$ after ecdysis and exoskeleton hardening, J1 crabs were subjected to experimental conditions similar to those for megalopae to preclude further growth to the second juvenile instar and thereby ensure substrate selection behavior characteristic of J1 crabs.

Trials were initiated at $17: 30 \mathrm{~h}$ by placing 10 ind. (either megalopae or $\mathrm{J} 1 \mathrm{crabs}$ ) into each of the 6 sections per mesocosm with partitions in place (i.e. total of 60 ind. per mesocosm). Densities of megalopae $\left(155 \mathrm{~m}^{-2}\right)$ used in our experiments approximated the maximum density $\left(160 \mathrm{~m}^{-2}\right)$ of blue crabs (plus megalopae) ever quantified from a Chesapeake Bay seagrass bed during the recruitment season (Orth \& van Montfrans 1987, J. van Montfrans \& R. J. Orth pers. obs.). After a $2 \mathrm{~h}$ acclimation period under fluorescent illumination, lights were turned off, partitions removed, and individuals allowed to redistribute among substrates. Trials were run under nocturnal conditions because megalopae ingress into settlement habitats during nighttime (Olmi 1994, 1995). Upon termination at $08: 30 \mathrm{~h}$ the following morning, partitions between sections in each mesocosm were simultaneously reinserted to isolate adjacent substrates, lights were turned on and substrates in each mesocosm section were sampled. Thus, the post-acclimation experimental duration of $13 \mathrm{~h}$ slightly exceeded the natural period of nocturnal activity for megalopae and J1 crabs.

Data from laboratory experiments were analyzed using a replicated goodness of fit G-test (Sokal \& Rohlf 1981), which examined the null hypothesis that experimental animals remained evenly distributed among substrates. Because some megalopae metamorphosed to $\mathrm{J} 1$ crabs overnight in megalopal trials, responses by megalopae and J1 crabs in these laboratory experiments were not independent; here, the total number of individuals (including megalopae that metamorphosed to J1 crabs) was used as the response variable. Given the short duration (13 h) of laboratory experiments and the even shorter time interval between metamorphosis of megalopae followed by shell hardening and termination of the experiment, this approach seemed reasonable. Variability in the rates of metamorphosis by megalopae between trials was analyzed using a 1-way ANOVA (Sokal \& Rolph 1981).

Field experiment. A field experiment was conducted during full moon on 11/12 October 1989, a period of expected high settlement (van Montfrans et al. 1990, 1995). A total of 15 replicates of 3 experimental treat- 
ments were established along 3 transects parallel to the shoreline (i.e. 5 treatments per transect) in the York River (1 $\mathrm{m}$ depth at mean low water) adjacent to the Virginia Institute of Marine Science (Fig. 2). Each replicate consisted of a plot containing 3 substrate treatments arranged in circular patches measuring $0.25 \mathrm{~m}$ in diameter $\left(\sim 0.05 \mathrm{~m}^{2}\right)$. Substrates were randomly oriented by compass heading and equally spaced at a $2 \mathrm{~m}$ distance from a central stake marking each plot. Plots were separated by 4 to $5 \mathrm{~m}$ of bare sand along each transect. Substrate patches in each replicate were established by replacing natural sediment with each of 3 substrate types being tested (Zostera marina, marsh mud, and live Crassostrea virginica). Z. marina cores measuring $0.25 \mathrm{~m}$ in diameter were collected in a local (Allen's Island) grassbed, transported to the experimental site, and placed into excavated holes at the prescribed randomized location after careful examination and removal of any associated blue crabs. Densities of $Z$. marina in translocated plots were equivalent to low densities ( $\leq 180$ shoots $\mathrm{m}^{-2}$; Orth \& Moore 1986) characteristic of natural inshore beds. Marsh mud was similarly translocated from a nearby marsh creek, whereas $C$. virginica treatments were established by placing 12 live oysters of medium size (similar to those used in laboratory experiments) within a $25 \mathrm{~cm}$ diameter circle to complete each experimental plot. These 3 substrates were selected because they contained the highest number of crabs overall during labora-
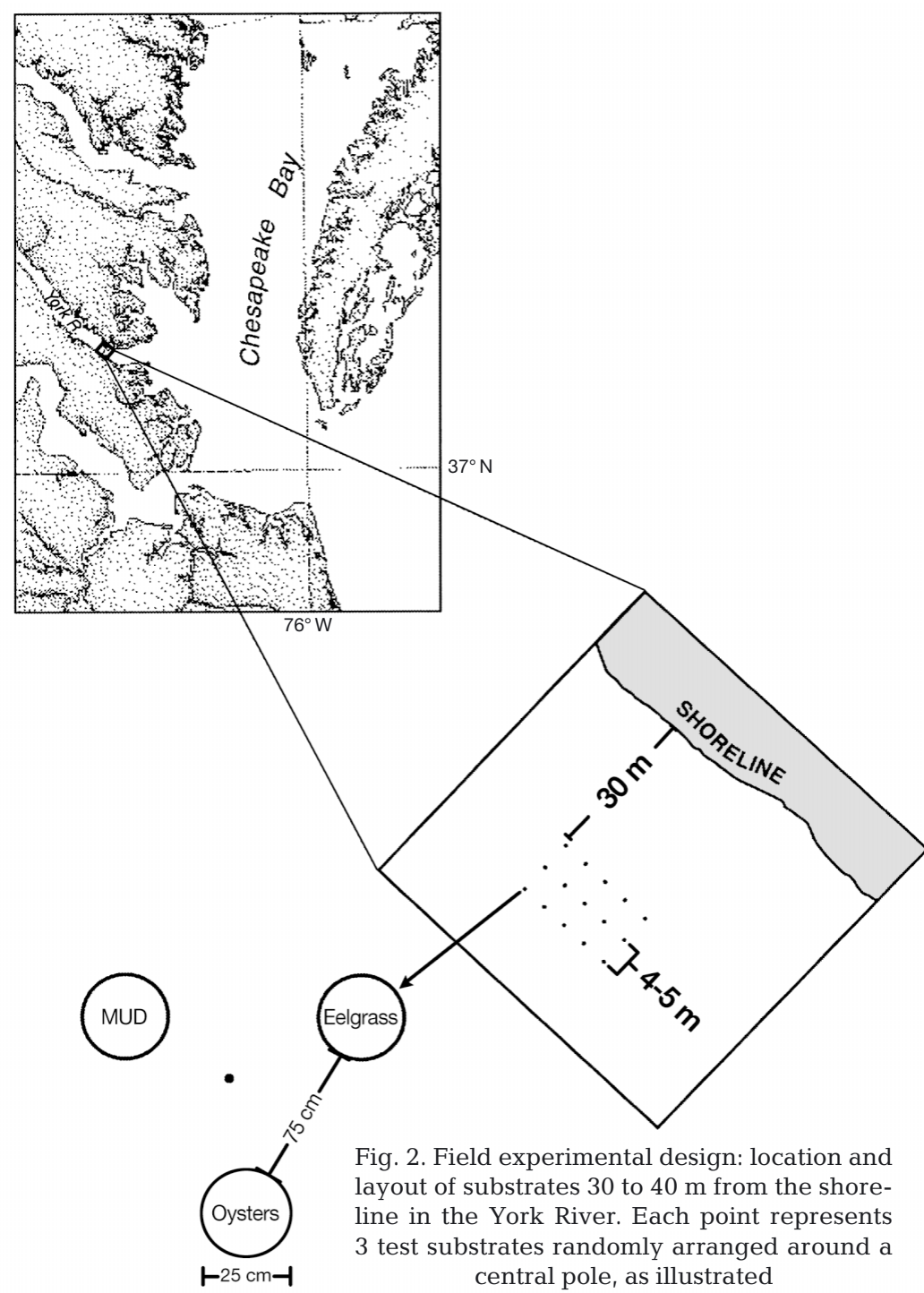
tory experiments utilizing megalopae or J1 crabs, and because they represented typical and readily available habitats in Chesapeake Bay.

Test substrates were collected from surrounding areas during the morning of 11 October and placed in the field between noon and 16:00 h. Substrates were randomly sampled early the following morning between 09:00 and 12:00 h. Thus, translocated substrates experienced a $12 \mathrm{~h}$ nocturnal period of megalopal recruitment activity and an average total duration in the field of about $21 \mathrm{~h}$. Though experimental duration differed between lab and field experiments, settlement into field-deployed substrates during daylight hours was likely minimal, since megalopae and J1 crabs move about primarily during nocturnal flood tides (van Montfrans et al. 1990, Olmi 1994, 1995).

Sampling was accomplished by fitting a screened cylindrical sampling frame over each plot and removing

colonized organisms using a suction sampler (Orth \& van Montfrans 1987) equipped with a fine-mesh $(0.50 \mathrm{~mm})$ plankton-net cod end. Differences in the mean number of megalopae and J1 crabs (response variables) in each substrate type (dependent variable) were analyzed separately in a 1-way ANOVA. Differences between means were determined using a Student-Newman-Keuls post-hoc test (Sokal \& Rolhf 1981).

\section{RESULTS}

Laboratory experiments. At the end of the experiment-after $13 \mathrm{~h}$ of darkness, during which megalopae (plus metamorphosed J1 crabs) in each mesocosm were free to move about-individuals were unevenly distributed among the 6 substrates in the pooled data set $(G \mathrm{p}$ [ $G$ for pooled data $]=125.52, \mathrm{df}=$ 

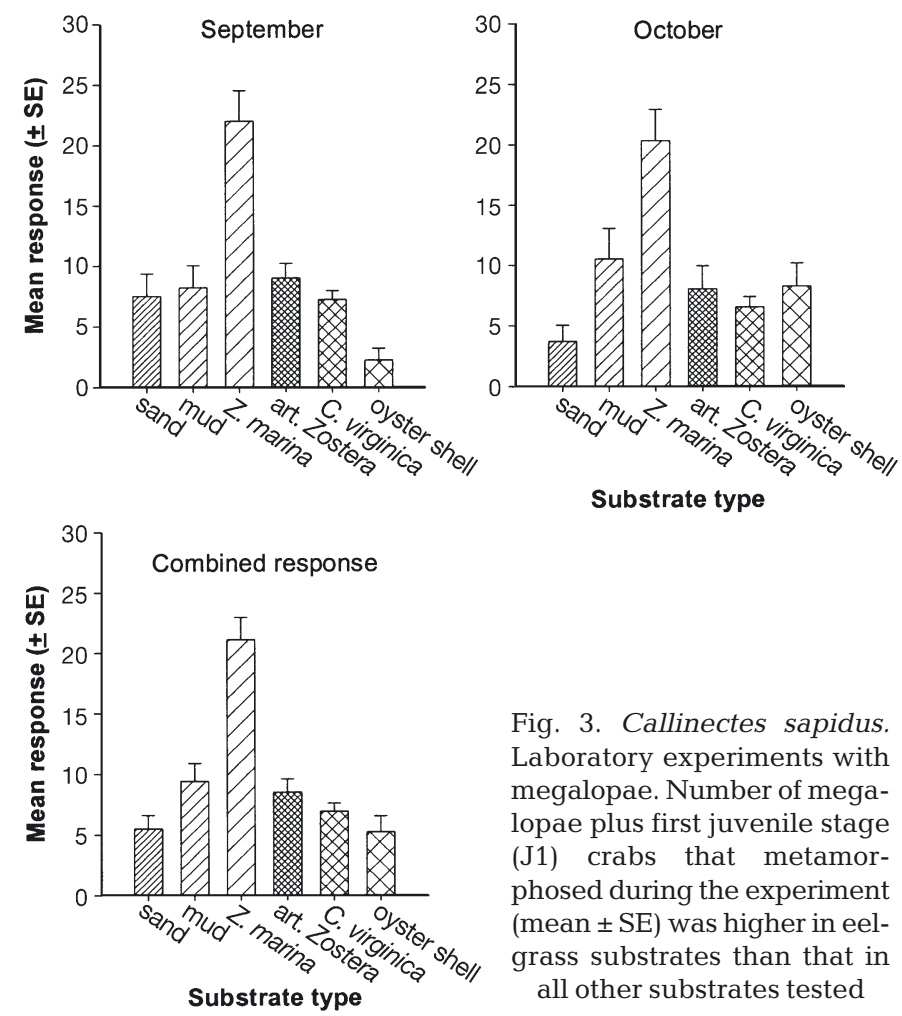

Fig. 3. Callinectes sapidus. Laboratory experiments with megalopae. Number of megalopae plus first juvenile stage (J1) crabs that metamorphosed during the experiment (mean $\pm \mathrm{SE}$ ) was higher in eelgrass substrates than that in all other substrates tested

5, p $<0.001)$. Although the distribution among substrates differed somewhat between the 2 trial dates $(G \mathrm{~h}[G$ for heterogeneity] $=81.34, \mathrm{df}=35, \mathrm{p}<0.001)$, the number of individuals recovered from live Zostera marina was twice that found in any of the other substrates (Fig. 3). The mean rate of metamorphosis $( \pm \mathrm{SE})$ by megalopae into J1 crabs differed between trial dates (September: $\bar{X}=37.0 \pm 5.0 \%$; October: $\bar{X}=$ $15.6 \pm 3.2 \%)$; ANOVA: $\left.F_{1,8}=17.85, \mathrm{p}<0.003\right)$, suggesting greater megalopal settlement competency during the earlier trials.

Similar experiments with J1 crabs produced a different outcome. As in experiments testing megalopae, J1 crabs were unevenly distributed among the 6 substrates in the pooled data set $(G \mathrm{p}=114.82$, df $=5, \mathrm{p}<$ 0.001 ), and some heterogeneity between trial dates $(G \mathrm{~h}=166.58, \mathrm{df}=84, \mathrm{p}<0.001)$ was evident. However in contrast to trials utilizing megalopae, the largest number of J1 crabs (Fig. 4) was recovered from live Crassostrea virginica ( $\bar{x}=17.2$ ind.; $\sim 30 \%$ of total) rather than live Zostera marina $(\bar{x}=9.6$ ind.; $~ 17 \%$ of total).

Field experiments. Both megalopae and J1 crabs preferred live Zostera marina when compared to live oysters and marsh mud in field experiments. Significantly more megalopae were recovered from live $Z$. marina $(\bar{x}=3.3)$ than from either mud $(\bar{x}=0.9)$ or live oyster substrates $(\bar{x}=1.3 ;$ Z marina $>$ oyster $=$ mud, SNK comparison,
ANOVA: $F_{2,42}=8.93, \mathrm{p} \leq 0.001$; Fig. 5a). Similarly, J1 crab abundance (Fig. 5b) was greatest in live $Z$. marina $(\bar{X}=3.7)$ when compared to mud $(\bar{X}=1.2)$ and oyster, $(\bar{x}=$ 1.8). substrates, which had equivalent abundances; SNK comparison, ANOVA: $\left.F_{2,24}=12.88, \mathrm{p}<0.001\right)$. Overall, $60 \%$ of all megalopae and $55 \%$ of $\mathrm{J} 1$ crabs recovered from experimental field plots occurred in Z $Z$. marina.

\section{DISCUSSION}

We demonstrated in our experiments that blue crab megalopae are capable of discriminating between experimental substrates in both the laboratory and field. The ability of megalopae to discriminate between live Zostera marina over other substrates tested explains, in part, the high densities of early-stage juvenile crabs found in natural eelgrass habitats. Comparisons in laboratory trials suggest further that such behavior is probably mediated by chemical rather than structural cues associated with $Z$ marina, since megalopae consistently selected live, cleaned $Z$. marina over inert eelgrass mimics. Such behavior likely acts in concert with physical (e.g. hydrodynamic) processes to cause aggregations of individuals during settlement in nature.

Megalopae in our laboratory experiments did not choose live Zostera marina substrates simply because they were $3 \mathrm{D}$, structurally complex and more readily encountered than other substrates offered. Artificial Z. marina was similar in gross morphology (though
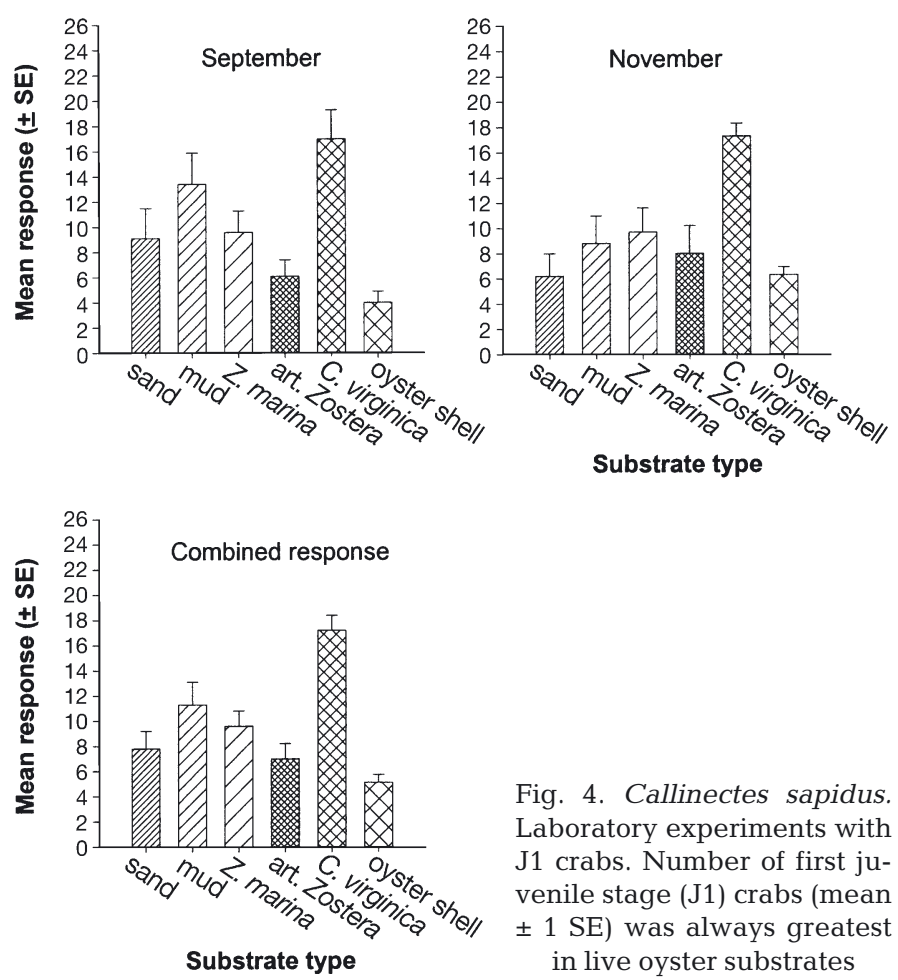

Fig. 4. Callinectes sapidus. Laboratory experiments with J1 crabs. Number of first juvenile stage (J1) crabs (mean $\pm 1 \mathrm{SE}$ ) was always greatest in live oyster substrates 


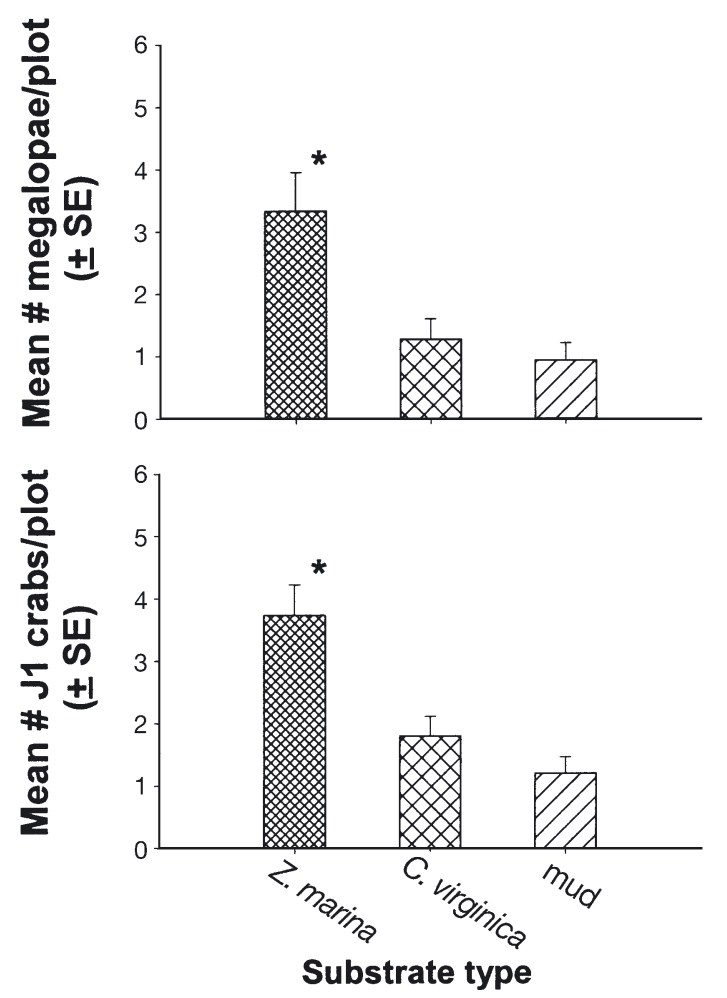

Fig. 5. Callinectes sapidus. Field experiment: number of (a) megalopae and (b) first juvenile stage (J1) crabs (mean \pm SE) found in substrates tested in nature. Megalopae and J1 crabs exhibited similar responses, with eelgrass containing significantly (*) greater numbers of individuals than live oyster and mud substrates

blades were slightly wider and therefore overall surface area was somewhat greater) to live $Z$. marina; yet, on average, more than 3 times as many megalopae occurred in living, actively metabolizing plants than in artificial simulations. J1 crabs that metamorphosed during laboratory experiments showed similar responses to those in field experiments, suggesting that J1 crabs in field trials settled as megalopae, metamorphosed, and thereafter remained in the same habitat. Thus, the presence of recently metamorphosed J1 crabs probably reflected habitat selection while megalopae.

Our findings confirm suggestions by Orth \& van Montfrans (1987) and Olmi et al. (1990) that colonization of seagrass beds in Chesapeake Bay occurs via the megalopa stage. Olmi et al. (1990) also indicated that J1 crab abundance reflected megalopal densities in the plankton, implying that the delivery of, and subsequent settlement by, megalopae are responsible for the initial densities of J1 crabs in seagrass beds. Physical forces that deliver megalopae to shallow-water areas undoubtedly act in concert with habitat-selection behavior to ultimately determine the initial distribution of blue crabs in nature.
Several investigations provide conflicting evidence for the ability of megalopae to actively orient toward and select settlement sites. Diaz et al. (1999) suggested that chemical and visual cues function in predator avoidance rather than habitat selection. Welch et al. (1997) found that blue crab megalopae are attracted to seagrass (Zostera marina and Halodule wrightii) cues, but avoid cues associated with salt marsh vegetation (Spartina alterniflora) and predators (UCa spp., Panopeus herbstii, Palaemonetes pugio). In contrast, Morgan et al. (1996) concluded that the ability of megalopae to discriminate between 3 types of experimentally transplanted vegetation (Ruppia maritima, $S$. alterniflora and Juncus roemerianus) was inconclusive due to low statistical power. However, strong nonsignificant trends in preference for seagrass ( $R$. maritima) during periods of low megalopal abundance and $S$. alterniflora when settlement was high indicated that additional investigation into such processes is warranted.

Whereas megalopae preferred live Zostera marina substrates in our laboratory experiments, previously metamorphosed J1 stages of the blue crab did not. Rather, J1 crabs occurred predominantly in Crassostrea virginica, with more than 3 times the number of individuals found in live oysters than in sub-bleached shell substrates. Thus, like megalopae, J1 crabs also seem to respond to chemical rather than structural cues. Whether the apparent lack of preference by J1 crabs for live $Z$. marina is simply a laboratory artifact or an indication that J1 crabs actually change their habitat selection behavior is unclear.

Blue crabs are well known for their aggressive behavior (Mansour \& Lipcius 1991) and cannibalistic tendencies (Mansour 1992, Moksnes et al. 1997) leading to density-dependent mortality or dispersal (Olmi et al. 1990, Pile et al. 1996, Moksnes et al. 1997, Etherington \& Eggleston 2000, Heck et al. 2001). Although mortality (or loss) of megalopae and J1 crabs in our laboratory experiments was minimal, as evidenced by high recovery rates of experimental organisms, the limited amount of space available within each substrate offered $\left(\sim 0.06 \mathrm{~m}^{2}\right)$ was likely too restrictive to accommodate the high densities of individuals. Thereby, their redistribution to other, potentially less desirable experimental substrates could have been affected by densitydependent interactions.

Density-dependent agonism as a mechanism for redistributing $\mathrm{J} 1$ crabs in our laboratory experimental treatments is likely. Olmi et al. (1990) evoked densitydependence as the cause of low spatial and temporal variability in natural juvenile crab densities, despite the occurrence of settlement peaks by megalopae at some sites but not others. Moksnes et al. (1997) suggested that relatively high rates of cannibalism and 
agonism between J9 (9th juvenile) crabs and smaller (megalopae and J3) crabs could induce crab dispersal. Density-dependent agonism as a mechanism for postsettlement dispersal of newly settled crabs in North Carolina habitats was also evoked by Etherington \& Eggleston (2000). Thus, density-dependent interactions can have a strong effect on post-settlement abundance patterns in nature (Olmi et al. 1990, Pile et al. 1996, Moksnes et al. 1997, Pardieck et al. 1999, Etherington \& Eggleston 2000 (Moksnes 2002) and may also have been a factor in our experimental results.

Physiological state might also influence settlement of megalopae (Welch et al. 1997, Diaz et al. 1999). Previous studies conducted in the York River (Lipcius et al. 1990, Metcalf \& Lipcius 1992) found that almost all individuals are in pre-molt by the time they reach our experimental field site. Though we did not quantify physiological state, the competency for settlement of the megalopae used in our laboratory experiments differed between trial dates, as evidenced by the significantly different rates of metamorphosis to J1 crabs (37\% in September vs $16 \%$ in October). However, this factor did not substantially affect substrate selection behavior in our experiments (sensu Diaz et al. 1999).

Other factors such as predation (including cannibalism) could also affect post-settlement distribution. Mortality in our field experiment via fish or conspecific predation may have influenced the numbers of megalopae and J1 crabs found in experimental substrates, even though no small predatory fish such as gobies, blennies or shrimp (Plaemonetes spp., Crangon septemspinosa), or larger conspecifics, were found in our samples. Nevertheless, as local predators increase their feeding activity between dawn and dusk (Raffaelli \& Hawkins 1996), habitat-specific predation might have confounded substrate selection results in the field. Cannibalism among recruited crabs, in particular, could have altered post-settlement survival (Moksnes et al. 1997, Moksnes 2002) in a habitatspecific manner. Cannibalism was minimal in our laboratory experiments, since a high percentage of experimental individuals were recovered and individuals were similar in size throughout the short experimental time period. It is likely that both habitatselection behavior and predation interact in nature to influence initial distributions of early-stage juveniles.

The significantly greater number of newly recruited blue crabs quantified in previous studies from natural seagrass habitats relative to marsh creeks (Orth \& van Montfrans 1987) can be explained, in part, by habitat preference behavior, and adds to the importance of vegetated habitats as nurseries (sensu Beck et al. 2001). Relatively high densities of crabs in seagrass habitats are maintained via reduced mortality of juvenile crabs (Pile et al. 1996, Schulman 1996, Orth \& van Montfrans 2002). Survival increases with crab size (Pile et al. 1996, Orth \& van Montfrans 2002) as a function of shoot density (Schulman 1996). Thus, the accelerated growth rates exhibited by crabs in seagrass beds (Perkins-Visser et al. 1996) might impart an advantage for survival to that segment of the population in vegetated habitats.

Overall, the process of recruitment for blue crabs is complex and involves several intrinsic (i.e. physiological, behavioral) and extrinsic (i.e. currents, predation etc.) factors. Megalopae in the coastal ocean initiate vertical migration behavior when they encounter general, broadscale estuarine cues (sensu Forward 1989, Forward et al. 1996, 1997), thereby enhancing their return from the coastal ocean to estuaries. Finer-scale habitat-specific cues (Welch et al. 1997, this study) determine, in part, the initial distribution of megalopae and J1 crabs within estuarine nursery habitats. Specific responses to estuarine nursery habitat types (e.g. seagrass beds, algal habitats) assure the greatest likelihood of recruitment success via accelerated metamorphosis to the J1 stage (Forward et al. 1994, 1996, Wolcott \& DeVries 1994, Brumbaugh \& McConaugha 1995), maximal survival (Pile et al. 1996, Orth \& van Montfrans 2002) and accelerated growth (Perkins-Visser et al. 1996). Similar relationships may also occur in other estuarine-dependent species with comparable habitat requirements and similar life-history characteristics.

Acknowledgements. We are indebted to P. Sadler and S. Mauger, in particular, and other technical staff for their assistance in laboratory and field experiments. We also greatly appreciate critical reviews and helpful suggestions by $P$. Moksnes and 2 anonymous reviewers for improvements to the manuscript. This research was supported by NOAA research grants \#NA-85AA-DSG016 and DSG042 to R. J. O. \& J. v. M. This is contribution \#2538 from the Virginia Institute of Marine Science, The College of William and Mary.

\section{LITERATURE CITED}

Beck MW, Heck KL Jr, Able KW, Childers DL and 9 others (2001) The identification, conservation, and management of estuarine and marine nurseries for fish and invertebrates. Bio Sci 51:633-641

Botero L, Atema J (1982) Behavior and substrate selection during larval settling in the lobster, Homarus americanus. J Crustac Biol 2:59-69

Boudreau B, Bourget E, Simrad Y (1990) Benthic invertebrate response to substrate characteristics at settlement: shelter preferences of the American lobster Homarus americanus. Mar Biol 106:191-198

Brumbaugh R, McConaugha JR (1995) Time to metamorphosis of blue crab Callinectes sapidus megalopae: effects of benthic macroalgae. Mar Ecol Prog Ser 129:113-118

Butman CA (1987) Larval settlement of soft-sediment invertebrates: the spatial scales of pattern explained by active habitat selection and the emerging role of hydrodynamical processes. Oceanog Mar Biol Annu Rev 25:113-165 
Butman CA, Grassle JP, Webb CM (1988) Substrate choices made by marine larvae settling in still and flowing water and in a flume flow. Nature 333(6175):771-773

Castro P (1978) Settlement and habitat selection in the larvae of Echinoecius pentagonus (A. Milne Edwards), a brachyuran crab symbiotic with sea urchins. J Exp Mar Biol Ecol 34:254-270

Connell JH (1985) The consequences of variation in initial settlement vs post-settlement mortality in rocky intertidal communities. J Exp Mar Biol Ecol 93:11-45

Costlow JD Jr, Bookhout CG (1959) The larval development of Callinectes sapidus Rathbun reared in the laboratory. Biol Bull 116:373-396

De Vries MC, Tankersley RA, Forward RB Jr, Kirby-Smith WW, Luettich RA Jr (1994) Abundance of estuarine crab larvae associated with tidal hydrologic variables. Mar Biol 118:403-413

Diaz H, Orihuela B, Forward RB Jr, Ritschoff D (1999) Orientation of blue crab Callinectes sapidus Rathbun megalopae: responses to visual and chemical cues. J Exp Mar Biol Ecol 233:25-40

Epifanio CE (1988a) Transport of invertebrate larvae between estuaries and the Continental Shelf. Am Fish Soc Symp 3:104-114

Epifanio CE (1988b) Dispersal strategies of two species of swimming crabs on the continental shelf adjacent to Delaware Bay. Mar Ecol Prog Ser 49:243-248

Epifanio CE, Valenti CC, Pembroke AE (1984) Dispersal and recruitment of blue crab larvae in the Delaware Bay, USA. Estuar Coast Shelf Sci 18:1-12

Epifanio CE, Masse AK, Gravine RW (1989) Transport of blue crab larvae by surface currents off Delaware Bay, USA. Mar Ecol Prog Ser 54:35-41

Etherington LL, Eggleston DB (2000) Large-scale blue crab recruitment: linking postlarval transport, post-settlement planktonic dispersal, and multiple nursery habitats. Mar Ecol Prog Ser 204:179-98

Fernandez M, Irbane O, Armstrong D (1993) Habitat selection by young-of-year Dungeness crab, Cancer magister Dana and predation risk in intertidal habitats. Mar Ecol Prog Ser 92:171-177

Forward RB Jr (1989) Behavioral responses of crustacean larvae to rates of salinity change. Biol Bull 176:229-238

Forward RB Jr, Frankel DAZ, Rittschof D (1994) Molting of megalopae from the blue crab Callinectes sapidus: effects of offshore and estuarine cues. Mar Ecol Prog Ser 113: 55-59

Forward RB Jr, Tankersley RA, De Vries MC, Rittschof D (1995) Sensory physiology and behavior of blue crab (Callinectes sapidus) postlarvae during horizontal transport. Mar Freshw Behav Physiol 26:233-248

Forward RB Jr, De Vries MC, Rittschof D, Frankel DAZ, Bischoff JP, Fisher CM, Welch JM (1996) Effects of environmental cues on metamorphosis of the blue crab Callinectes sapidus. Mar Ecol Prog Ser 131:165-177

Forward RB Jr, Swanson J, Tankersley RA, Welch JM (1997) Endogenous swimming rhythms of blue crab, Callinectes sapidus, megalopae: effects of offshore and estuarine cues. Mar Biol 127:621-628

Goodrich DM, van Montfrans J, Orth RJ (1989) Blue crab megalopal influx to Chesapeake Bay: evidence for a winddriven mechanism. Estuar Coast Shelf Sci 29:247-260

Hadfield MG (1984) Settlement requirements of molluscan larvae: new data on chemical and genetic roles. Aquaculture 39:283-298

Harvey AW (1993) Larval settlement and metamorphosis in the sand crab Emerita talpoida (Crustacea:Decapoda:
Anomura). Mar Biol 117:575-581

Heck KL Jr, Cohen LD, Morgan SG (2001) Pre- and postsettlement factors as determinants of juvenile blue crab Callinectes sapidus abundance: results from the northcentral Gulf of Mexico. Mar Ecol Prog Ser 222:163-176

Hedvall O, Moksnes PO, Pihl L (1998) Active habitat selection by megalopae and juvenile shore crabs, Carcinus meanas: a laboratory study in an annular flume. Hydrobiologia 375/376:89-100

Hernkind WF, Butler MJ (1986) Factors regulating postlarval settlement and juvenile microhabitat use by spiny lobsters Panulirus argus. Mar Ecol Prog Ser 34:23-30

Jensen GC (1989) Gregarious settlement of megalopae of the porcelain crab Petrolisthes cinctipes (Randall) and P. eriomerus Stimpson. J Exp Mar Biol Ecol 13(1):223-231

Lipcius RN, Olmi EJ III, van Montfrans J (1990) Planktonic availability, molt stage and settlement of blue crab postlarvae. Mar Ecol Prog Ser 58:235-242

Luckenbach MW, Orth RJ (1992) Swimming velocities and behavior of blue crab (Callinectes sapidus Rathbun) megalopae in still and flowing water. Estuaries 15:186-192

Mansour RA (1992) Foraging ecology of the blue crab, Callinectes sapidus Rathbun, in lower Chesapeake Bay. PhD thesis, College of William and Mary, Gloucester Point, VA

Mansour RA, Lipcius RN (1991) Density-dependent foraging and mutual interference in blue crabs preying upon infaunal clams. Mar Ecol Prog Ser 72:239-246

Mense DJ, Wenner EL (1989) Distribution and abundance of early life history stages of the blue crab, Callinectes sapidus, in tidal marsh creeks near Charleston, South Carolina. Estuaries 12:157-168

Metcalf KS, Lipcius RN (1992) Relationship of habitat and spatial scale with physiological state and settlement of blue crab postlarvae in Chesapeake Bay. Mar Ecol Prog Ser 82:143-150

Minello TJ (1999) Nekton densities in shallow water estuarine habitats of Texas and Louisiana and the identification of essential fish habitat. Am Fish Soc Symp 22:43-75

Moksnes PO (2002) The relative importance of habitatspecific settlement, predation and juvenile dispersal for distribution and abundance of young shore crabs, Carcinus maenas L. J Exp Mar Biol Ecol 271:41-73

Moksnes PO, Lipcuis RN, Pihl L, van Montfrans J (1997) Cannibal-prey dynamics in young juveniles and postlarvae of the blue crab. J Exp Mar Biol Ecol 215:157-187

Morgan SG, Zimmer-Faust RK, Heck KL Jr, Coen LD (1996) Population regulation of blue crabs Callinectes sapidus in the northern Gulf of Mexico: postlarval supply. Mar Ecol Prog Ser 133:73-88

Morse DE (1990) Recent progress in larval settlement and metamorphosis: closing the gaps between molecular biology and ecology. Bull Mar Sci 46:465-483

O'Connor NJ (1991) Flexibility in timing of the metamorphic molt by fiddler crab megalopae Uca pugilator. Mar Ecol Prog Ser 68:243-247

Olmi EJ III (1994) Vertical migration of blue crab Callinectes sapidus megalopae: implications for transport in estuaries. Mar Ecol Prog Ser 113:39-54

Olmi EJ III (1995) Ingress of blue crab megalopae in the York River, Virginia, 1987-1989. Bull Mar Sci 57:753-780

Olmi EJ III, van Montfrans J, Lipcius RN, Orth RJ, Sadler PW (1990) Variation in planktonic availability and settlement of blue crab megalopae in the York River, Virginia. Bull Mar Sci 46:230-243

Orth RJ, Moore KA (1986) Seasonal and year-to-year variation in the growth of Zostera marina L. (eelgrass) in lower Chesapeake Bay. Aquat Bot 24:335-341 
Orth RJ, van Montfrans J (1987) Utilization of a seagrass meadow and tidal marsh creek by blue crabs Callinectes sapidus. I. Seasonal and annual variations on abundance with emphasis on post-settlement juveniles. Mar Ecol Prog Ser 41:283-294

Orth RJ, van Montfrans J (1990) Utilization of marsh and seagrass habitat by early stages of Callinectes sapidus: a latitudinal perspective. Bull Mar Sci 46:126-144

Orth RJ, van Montfrans J (2002) Habitat quality and prey size as determinants of survival in post-larval and early juvenile instars of the blue crab Callinectes sapidus. Mar Ecol Prog Ser 231:205-213

Pardieck RA, Orth RJ, Diaz RJ, Lipcius RN (1999) Ontogenetic changes in habitat use by postlarvae and young juveniles of the blue crab. Mar Ecol Prog Ser 186:227-238

Pechenick JA (1990) Delayed metamorphosis by larvae of benthic invertebrates: does it occur? Is there a price to pay? Ophelia 32:63-94

Perkins-Visser E, Wolcott TG, Wolcott DL (1996) Nursery role of seagrass beds: enhanced growth of juvenile blue crabs (Callinectes sapidus Rathbun). J Exp Mar Biol Ecol 198: 155-173

Pile AJ, Lipcius RN, van Montfrans J, Orth RJ (1996) Densitydependent settler-recruit-juvenile relationships in blue crabs. Ecol Monogr 66:277-300

Raffaelli D, Hawkins S (1996) Intertidal ecology. Chapman \& Hall, London

Rodriguez SR, Ojeda FP, Inestrosa NC (1993) Settlement of benthic marine invertebrates. Mar Ecol Prog Ser 97:193-207

Rozas LP, Minello TJ (1998) Necton use of salt marsh, seagrass and unvegetated habitats in a South Texas estuary. Bull Mar Sci 63:481-501

Scheltema RS (1974) Biological interactions determining larval settlement of marine invertebrates. Thalas Jugoslav 10:263-296

Editorial responsibility: Kenneth Heck (Contributing Editor), Dauphin Island, Alabama, USA
Scheltema RS (1986) On dispersal and planktonic larvae of benthic invertebrates: a eclectic overview and summary of problems. Bull Mar Sci 39:290-322

Schulman JL (1996) Habitat complexity as a determinant of juvenile blue crab survival. MSc thesis, The College of William and Mary, Gloucester Point, VA

Sokal RR, Rohlf FJ (1981) Biometry, 2nd edn. WH Freeman, New York

Tankersley RA, Forward RB Jr (1994) Endogenous swimming rhythms in estuarine crab megalopae: implications for flood-tide transport. Mar Biol 118:415-423

Thomas JL, Zimmerman RJ, Minello TJ (1990) Abundance patterns of juvenile blue crabs (Callinectes sapidus) in nursery habitats of two Texas bays. Bull Mar Sci 46:115-125

van Montfrans J, Peery CA, Orth RJ (1990) Daily, monthly and annual settlement patterns by Callinectes sapidus and Neopanope sayi megalopae on artificial collectors deployed in the York River, Virginia: 1985-1988. Bull Mar Sci 46:214-229

van Montfrans J, Epifanio CE, Knott DM, Lipcius RN and 7 others (1995) Settlement of blue crab megalopae in western Atlantic estuaries. Bull Mar Sci 57:834-854

Welch JM, Rittschof D, Bullock RM, Forward RB Jr (1997) Effects of chemical cues on settlement behavior of blue crab Callinectes sapidus postlarvae. Mar Ecol Prog Ser 154:143-153

Williams AB (1984) Shrimps, lobsters, and crabs of the Atlantic coast of the eastern United States, Maine to Florida. Smithsonian Institution Press, Washington, DC

Wolcott DL, MC De Vries (1994) Offshore megalopae of Callinectes sapidus: depth of collection, molt stage and response to environmental cues. Mar Ecol Prog Ser 109: $157-163$

Young CM (1990) Larval ecology of marine invertebrates: a sesquicentennial history. Ophelia 32:1-48

Submitted: May 13, 2002; Accepted: April 10, 2003

Proofs received from author(s): September 8, 2003 